\title{
Editorial
}

\section{Double Blind Peer-Review in Philosophies}

\author{
Marcin J. Schroeder $1, *(\mathbb{D})$ and Carla Aloè ${ }^{2}$ \\ 1 Institute for Excellence in Higher Education, Tohoku University, Sendai 980-8576, Japan \\ 2 MDPI AG, St. Alban-Anlage 66, 4052 Basel, Switzerland; carla.aloe@mdpi.com \\ * Correspondence: mjs@gl.aiu.ac.jp
}

Citation: Schroeder, M.J.; Aloè, C. Double Blind Peer-Review in

Philosophies. Philosophies 2021, 6, 36.

https://doi.org/10.3390/philosophies 6020036

Received: 25 April 2021

Accepted: 25 April 2021

Published: 26 April 2021

Publisher's Note: MDPI stays neutral with regard to jurisdictional claims in published maps and institutional affiliations.

\section{Copyright: (c) 2021 by the authors.} Licensee MDPI, Basel, Switzerland. This article is an open access article distributed under the terms and conditions of the Creative Commons Attribution (CC BY) license (https:// creativecommons.org/licenses/by/ $4.0 /)$.
Peer-review has become increasingly important to the way scholarly journals assess whether a manuscript is suitable for publication. It is extremely important that the process is fair, robust, constructive and free of bias. Blinding is one of the main strategies adopted by publishers in order to achieve these goals. Since its inaugural issue released in 2016, Philosophies has been following a single-blind review process, where the reviewers' identities are not revealed to the authors.

The Editor-in-Chief of the journal, along with the Editorial Office, would like to announce that a double-blind review will be applied to all of the manuscripts submitted to Philosophies, starting from today. All of the articles published in our next issue (released on 22 June 2021) will undergo a double-blind review. This means that, in addition to authors not knowing the identities of reviewers, reviewers will not know the identities of the article's authors during the review process. With the introduction of this change, we aim to guarantee a more thorough editorial process, as well as to align Philosophies with the majority of the journals in the humanities field. We also believe that this process will benefit scholars without an established reputation.

We would like to take this opportunity to thank all of the anonymous reviewers who contribute to Philosophies' peer-review process. Their voluntary contributions, based on their experiences in the field, help us to maintain a high standard in our published articles and underpin our editorial process.

Conflicts of Interest: The authors declare no conflict of interest. 